\title{
Mediating Roles of Perceived Ease of Use and Perceived Enjoyment between Psychological Commitment to a Team and Loyalty to the Team's Website
}

Woo-Young Lee*

Although previous studies have considerably highlighted the importance of understanding various aspects of online sport consumer behavior (e.g., Brown, 2003; Filo \& Funk, 2005; Hur et al., 2007), few studies have been conducted to investigate sport fan behavior in the online context. The purpose of this study is to examine mediating roles of perceived ease of use and perceived enjoyment between psychological commitment to a team and loyalty to the team's website. The results of structural equation modeling analyses revealed that perceived enjoyment is a partial mediating variable when explaining the relationship. This result implies that sport marketers should develop and manage a team's website with fun and enjoyable content to make loyal fans loyal to the website.

\section{Introduction}

$\mathrm{I}_{\mathrm{s}}^{\mathrm{t}}$ $t$ is obvious that the sport industry has grown significantly year-by-year around the world and has become an integral part of many cultures (McMillen, 2009). According to Kim, Lindberg, and Monaldo (2009), the total expense that American customers spent on sport industry has increased $8.5 \%$ from $\$ 61$ billion in 2005 to $\$ 66.2$ billion in 2008. Along with the expansion of sport industry and growth of Internet users, sport companies' revenues from the Internet have become dramatically expanded over the past few decades (Hur, Ko, \& Valacich, 2007). For example, revenues from Internet advertising have greatly shifted from $\$ 8$ billion in 2000 to over $\$ 22$ billion in 2009 (The IAB PWC 2009 Internet Advertising Revenue Report, 2010).

Although previous studies have pointed out the importance of understanding various aspects of online sport consumer behavior (e.g., Brown, 2003; Filo \& Funk, 2005; Hur et al., 2007),

*Assistant Professor,Athletic \& Sports Business Administration Program,Department of Kinesiolog,University of Central Missouri, Humphreys few studies have been conducted to investigate the consumer behavior in the online context. In particular, major sport games have embraced the Internet as an alternate form of live broadcasting (Kaplan, 2009). For example, one of the biggest sport events, the 2010 Masters Golf Tournament, provided free live streaming in high definition in which banner ads were embedded. People can watch recent video clips about daily game highlights, interviews, or news on their favorite teams' websites. Despite the growth in uses and revenue, questions still remain, "what is the most important determinant that leads to use of a sport team's website?" In order to answer this question, we examined the effect of sport fans' psychological commitment to a sport team (Mahony, Madrigal, \& Howard, 2000) on their loyalty to the team's website with two mediators, perceived ease of use and perceived enjoyment. Considering that obtaining website user loyalty to a web portal is the key to survival in e-business ( $\mathrm{Lin}, \mathrm{Wu}, \&$ Tsai, 2005), understanding how loyal or committed fans develop their loyalty to the team's website is crucial for sport marketers to accomplish their goals on the website.

\section{Literature Review}




\section{Psychological commitment to a team}

Commitment is defined as "an enduring desire to maintain a valued relationship" (Moorman, Zaltman, \& Deshpandé, 1992, p. 316) and considered an important antecedent to customer loyalty (Beatty \& Kahle, 1988; Dimitriades, 2006). Commitment is considered a distinct construct from loyalty because it refers more to emotional and/or psychological attachments toward a brand, store, or service (Evanschitzky et al., 2006; Thomson, MacInnis, \& Park, 2005). Applying "resistance to change" in Pritchard, Havitz, \& Howard's (1999) study, Mahony et al. (2000) proposed the psychological commitment to a team (PCT) scale to examine sport fans' attitudinal commitment to a team. According to Iwasaki and Havitz (2004), psychological commitment is an antecedent of loyalty to a recreation agency. Evanschitzky, Iyer, Plassmann, Niessing, \& Meffert (2006) further supported that commitment plays a significant role in increasing attitudinal loyalty to a brand or a company. In the online retailers, commitment was found to be one of the core components of a positive relationship between the retailers and consumers (Eastlick, Lotz, \& Warrington, 2006). The affective commitment to a service provider has been emphasized in the relationship marketing because it positively influences loyalty (Fullerton, 2005).

As consumer loyalty is one of the most predominant factors for revenue generation of a business organization, loyalty to a website is also considered an important construct because it positively influences long-term profitability (Ribbink, van Riel, Liljander, \& Streukens, 2004) and word-of-mouth referrals (van Riel, Liljander, \& Jurriëns, 2001). Loyalty to a website is also called e-loyalty in Internetrelated research (e.g., Cyr, Bonanni, \& Ilsever, 2005). Loyalty to a sport team's website is defined as a sport fan's intention to revisit the website (Hur, Ko, \& Valacich, in press; Oliver, 1999). In the current study, loyalty to a sport team's website is a dependent variable, which is influenced by psychological commitment to a team, perceived ease of use, and perceived enjoyment.

Figure 1. A proposed model and hypotheses

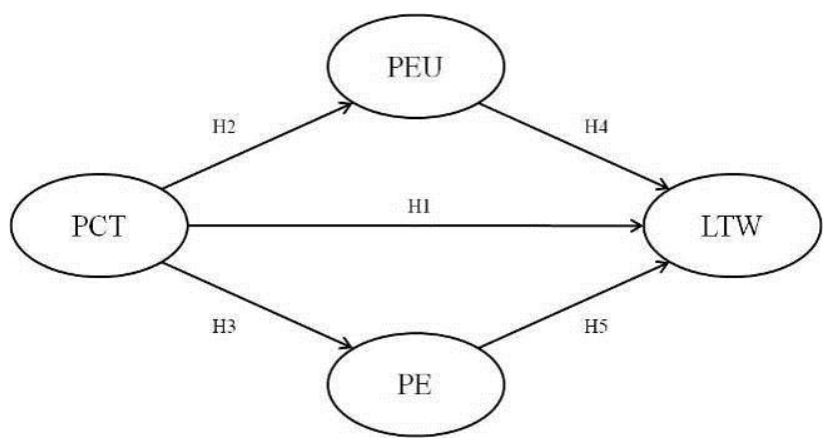

Note: PCT (psychological commitment to a team); PEU (perceived ease of use); $P E$ (perceived enjoyment); and LTW (loyalty to the website).

Perceived ease of use and perceived enjoyment

The technology acceptance model (TAM: Davis, 1989; Davis, Bagozzi, \& Warshaw, 1989) has been considered one of the most parsimonious and robust models in information systems. In the TAM, the intention to use a computer-based system is determined by perceived ease of use, perceived usefulness (Davis et al., 1989) and perceived enjoyment (Davis, Bagozzi, \& Warshaw, 1992; Moon \& Kim, 2001). The current study excluded perceived usefulness (PU) because it was found to be a non-significant predictor of user intention in a voluntary computer or Internet use such as web surfing (Atkinson \& Kydd, 1997). Therefore, the current study included two mediating variables, perceived ease of use (PEU) and perceived enjoyment (PE).

In addition, external variables in a computerbased system such as training, documentation, and user support consultants were added and were potential antecedents of PEU and PU (Davis et al., 1989). Likewise, in the current study, PCT was included as an external and independent variable that potentially influences PEU and PE in the proposed model. 
PEU is defined as the degree to which a sport fan believes that using his/her favorite team's website would be free of effort (Davis et al., 1989). If a sport fan perceives ease of use, he/she may realize this saved effort, and in turn may find more sport information with the same amount of effort. PE refers to the degree to which a sport fan believes that using his/her favorite team's website would be enjoyable. Studies have found that perceived enjoyment is one of the most important antecedents of intention to use the computer system in various settings (Eighmey \& McCord, 1998; van der Heijden \& Verhagen, 2004). Research in the field of consumer behavior has identified such enjoyment or fun in consumption behaviors by using hedonic value (Babin, Darden, \& Griffin, 1994; Batra \& Ahtola, 1990; Crowlely, Spangenberg, \& Hughes, 1992; Okada, 2005; Voss, Spangenberg, \& Grohmann, 2003). Hedonic value captures consumers' evaluation about a brand/product with regard to the enjoyment, pleasure, or fun involved in use of a product (Batra \& Ahtola, 1990; Voss et al., 2003). Enjoyment or fun has been found to be a predictor of attitude toward and use of websites (Eighmey \& McCord, 1998; Jarvenpaa \& Todd, 1997; Moon \& Kim, 2001). For example, a sport fan may perceive enjoyment or fun on a sport website by watching visual images, sharing opinions with the other fans, or watching live streaming.

Based on aforementioned theories and findings, the following hypotheses were generated in order to gauge the purpose of the current study.

H1. PCT is positively related with loyalty to the team's website.

H2. PCT is positively related with PEU.

H3. PCT is positively related with PE.

H4. PEU is positively related with loyalty to the team's website.
H5. PE is positively related with loyalty to the team's website.

\section{Methodology}

\section{Participants and scales}

A convenience sample method was employed. A survey was administered to sport participants within the Department of Recreational Sports at a university located in the Northwest region in the U.S. Each participant was asked whether he/she had experiences of using professional teams' official websites: 198 experienced people who completed the survey were included in the current study from 225. Of the 198 participants, 62.6\% $(\mathrm{n}=124)$ were male and $37.4 \%(\mathrm{n}=74)$ were female. Participant ages primarily fell between 19 and $22(\mathrm{M}=21.18$ years; $\mathrm{SD}=3.23)$. The majority ethnic background is Caucasian (71.7\%), followed by Asian-American (10.6\%).

All of the items (i.e., PCT, PEU, PE, and LTW) were measured with a nine-point Likert type scale format ranging from (1) "Strongly Disagree" to (9) "Strongly Agree." Psychological commitment to a team (PCT: Mahony et al., 2000) scale was adapted to measure individual loyalty level to a sport team. Among 10 items of the PCT scale, 6 items that had low item-to-total correlations were excluded in the current study.

The scales for perceived ease of use and perceived enjoyment were modified from the technology acceptance model (Davis, 1989; Davis et al., 1989; Moon \& Kim, 2001). Loyalty to the website scale was adapted from Oliver's (1997) loyalty scale. 
The Results of a Measurement Model Test

\begin{tabular}{|c|c|c|c|c|c|c|}
\hline Items & Mean & $\begin{array}{l}\text { Standard } \\
\text { Deviation }\end{array}$ & Loadings & $\begin{array}{l}\text { Critical } \\
\text { Ratio }\end{array}$ & $\begin{array}{l}\text { Composite } \\
\text { Reliability }\end{array}$ & AVE \\
\hline $\begin{array}{l}\text { PCT1. Being a fan of my favorite sport team } \\
\text { is important to me. }\end{array}$ & 7.01 & 1.91 & .62 & - & \multirow{4}{*}{.82} & \multirow{4}{*}{.54} \\
\hline $\begin{array}{l}\text { PCT2. It would be unlikely for me to change } \\
\text { my allegiance from my favorite sport team } \\
\text { to another. }\end{array}$ & 7.17 & 2.04 & .72 & $7.72 *$ & & \\
\hline $\begin{array}{l}\text { PCT3. It would be difficult to change my } \\
\text { beliefs about the team. }\end{array}$ & 6.89 & 1.85 & .77 & $8.14 *$ & & \\
\hline $\begin{array}{l}\text { PCT4. I am a committed fan of my favorite } \\
\text { sport. }\end{array}$ & 7.13 & 1.98 & .82 & $8.81 *$ & & \\
\hline $\begin{array}{l}\text { PEU1. The team's website is a user-friendly } \\
\text { site. }\end{array}$ & 6.57 & 1.71 & .75 & - & \multirow{3}{*}{.82} & \multirow{3}{*}{.61} \\
\hline $\begin{array}{l}\text { PEU2. It is easy to navigate around and find } \\
\text { what I want at this site. }\end{array}$ & 6.35 & 1.63 & .77 & $10.13 *$ & & \\
\hline $\begin{array}{l}\text { PEU3. I can quickly find the information } \\
\text { that I need in the team's website. }\end{array}$ & 6.28 & 1.66 & .82 & $10.38 *$ & & \\
\hline $\begin{array}{l}\text { PE1. I am excited when I use the team's } \\
\text { website. }\end{array}$ & 5.64 & 1.76 & .70 & $9.31 *$ & \multirow{3}{*}{.80} & \multirow{3}{*}{.57} \\
\hline PE2. It is fun to visit the team's website. & 6.13 & 1.72 & .78 & $10.79 *$ & & \\
\hline PE3. The team's website is entertaining. & 6.32 & 1.52 & .82 & - & & \\
\hline $\begin{array}{l}\text { LTW1. I have repeatedly found the web is } \\
\text { better than others. }\end{array}$ & 5.80 & 1.80 & .70 & - & \multirow{3}{*}{.88} & \multirow{3}{*}{.70} \\
\hline $\begin{array}{l}\text { LTW2. I always continue to favor the } \\
\text { offering of the team's website before } \\
\text { others. }\end{array}$ & 6.19 & 1.79 & .90 & $11.49^{*}$ & & \\
\hline $\begin{array}{l}\text { LTW3. I always choose to use the web in } \\
\text { preference to others. }\end{array}$ & 6.17 & 1.86 & .91 & $11.48^{*}$ & & \\
\hline
\end{tabular}

Note: * means at $p<.05 ;$ PCT (psychological commitment to a team); PEU (perceived ease of use); PE (perceived enjoyment); and LTW (loyalty to the website)

\section{Data Analysis Procedure}

To examine the proposed model

Figure 1. A proposed model and hypotheses

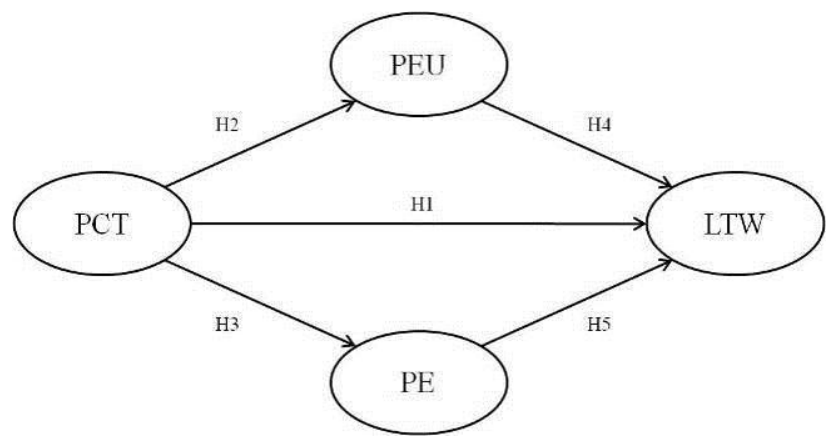

Note: PCT (psychological commitment to a team); PEU (perceived ease of use); PE (perceived enjoyment); and LTW (loyalty to the website). we employed structural equation modeling with AMOS 16. A full measurement model including all constructs (i.e., PCT, PEU, PE, and loyalty to the website) was tested to examine the reliability and the validity of the measures. The second step was to test the structural model and hypothesis tests, and mediating effects of PEU and PE. 


\section{Results}

Descriptive statistics and measurement model test

Confirmatory factor analysis with the maximum likelihood estimation was conducted to assess the extent to which each of the four variables was represented by its indicators. The four variables included PCT (psychological commitment to a team), PEU (perceived ease of use), PE (perceived enjoyment), and LTW (loyalty to the website). The test of measurement model resulted in a good fit to the data: $\chi 2(59, \mathrm{~N}=198)=92.31, \mathrm{p}<.01 ;$ RMSEA $=.054(.031-.074) ; \mathrm{CFI}=.97$. All the item loadings of the indicators were significant at $\mathrm{p}<$ .001 . The item loadings of the scale ranged from .62 to .82 for PCT; .75 to .82 for PEU; .70 to .82 for PE; and .70 to .91 for LTW. Construct reliabilities and average variance extracted (AVE) for each latent variable exceeded the recommended standard of .70 and .50 respectively (Hair, Anderson, Tatham, \& Black, 2005 ;

The Results of a Measurement Model Test

\begin{tabular}{|c|c|c|c|c|c|c|}
\hline Items & Mean & $\begin{array}{l}\text { Standard } \\
\text { Deviation }\end{array}$ & Loadings & $\begin{array}{c}\text { Critical } \\
\text { Ratio }\end{array}$ & $\begin{array}{l}\text { Composite } \\
\text { Reliability }\end{array}$ & AVE \\
\hline $\begin{array}{l}\text { PCT1. Being a fan of my favorite sport team } \\
\text { is important to me. }\end{array}$ & 7.01 & 1.91 & .62 & - & \multirow{4}{*}{.82} & \multirow{4}{*}{.54} \\
\hline $\begin{array}{l}\text { PCT2. It would be unlikely for me to change } \\
\text { my allegiance from my favorite sport team } \\
\text { to another. }\end{array}$ & 7.17 & 2.04 & .72 & $7.72 *$ & & \\
\hline $\begin{array}{l}\text { PCT3. It would be difficult to change my } \\
\text { beliefs about the team. }\end{array}$ & 6.89 & 1.85 & .77 & $8.14^{*}$ & & \\
\hline $\begin{array}{l}\text { PCT4. I am a committed fan of my favorite } \\
\text { sport. }\end{array}$ & 7.13 & 1.98 & .82 & $8.81 *$ & & \\
\hline $\begin{array}{l}\text { PEU1. The team's website is a user-friendly } \\
\text { site. }\end{array}$ & 6.57 & 1.71 & .75 & - & \multirow{3}{*}{.82} & \multirow{3}{*}{.61} \\
\hline $\begin{array}{l}\text { PEU2. It is easy to navigate around and find } \\
\text { what I want at this site. }\end{array}$ & 6.35 & 1.63 & .77 & $10.13^{*}$ & & \\
\hline $\begin{array}{l}\text { PEU3. I can quickly find the information } \\
\text { that I need in the team's website. }\end{array}$ & 6.28 & 1.66 & .82 & $10.38 *$ & & \\
\hline $\begin{array}{l}\text { PE1. I am excited when I use the team's } \\
\text { website. }\end{array}$ & 5.64 & 1.76 & .70 & $9.31 *$ & \multirow{3}{*}{.80} & \multirow{3}{*}{.57} \\
\hline PE2. It is fun to visit the team's website. & 6.13 & 1.72 & .78 & $10.79 *$ & & \\
\hline PE3. The team's website is entertaining. & 6.32 & 1.52 & .82 & - & & \\
\hline $\begin{array}{l}\text { LTW1. I have repeatedly found the web is } \\
\text { better than others. }\end{array}$ & 5.80 & 1.80 & .70 & - & \multirow{3}{*}{.88} & \multirow{3}{*}{.70} \\
\hline $\begin{array}{l}\text { LTW2. I always continue to favor the } \\
\text { offering of the team's website before } \\
\text { others. }\end{array}$ & 6.19 & 1.79 & .90 & $11.49 *$ & & \\
\hline $\begin{array}{l}\text { LTW3. I always choose to use the web in } \\
\text { preference to others. }\end{array}$ & 6.17 & 1.86 & .91 & $11.48^{*}$ & & \\
\hline
\end{tabular}

Note: * means at $p<.05 ;$ PCT (psychological commitment to a team); PEU (perceived ease of use); PE (perceived enjoyment); and LTW (loyalty to the website) 


\section{Hypothesis and mediator effect tests}

This study examined whether PCT made sport fans perceive ease of use and enjoyment on their favorite team's website, and whether the two mediators (i.e., PEU and PE) increased their loyalty to the team's website.

Figure 1. A proposed model and hypotheses

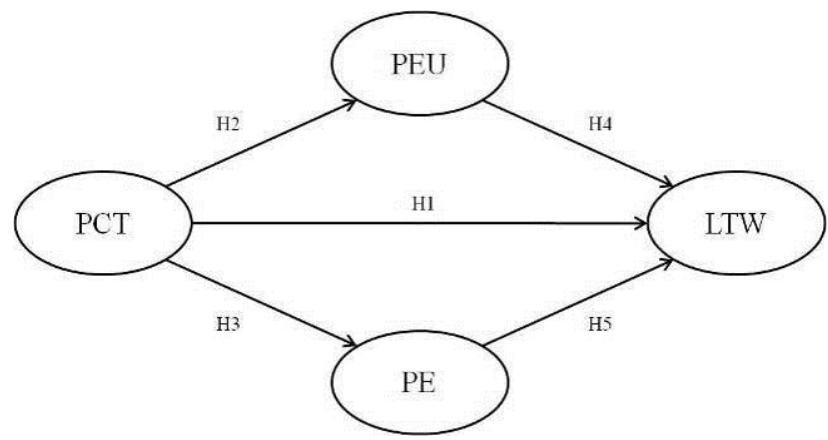

Note: PCT (psychological commitment to a team); PEU (perceived ease of use); $P E$ (perceived enjoyment); and LTW (loyalty to the website).

The structural equation modeling approach with AMOS 16 was used to test hypotheses. The proposed model resulted in an acceptable fit to the data: $\chi 2(60, \mathrm{~N}=198)=153.45, \mathrm{p}<.0001$; RMSEA $=.089(.072-.106) ; \mathrm{CFI}=.93 ; \mathrm{IFI}=$ .93 ; and TLI $=.91$, and accounted for $50.0 \%$ of the variance in LTW. All structural path coefficients were statistically significant except for the direct path from PEU to LTW, which was estimated at 15 .

Figure 2.Path diagram of the relationship between PCT and LTW through PEU and PE

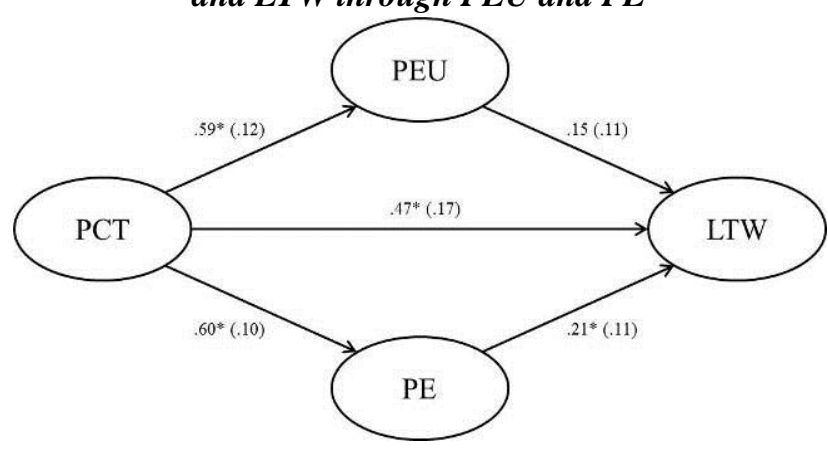

Note: * means a significant path coefficient at $p<.05$;

PCT (psychological commitment to a team); PEU (perceived ease of use); PE (perceived enjoyment); and LTW (loyalty to the website)
Therefore, all hypotheses were confirmed except for hypothesis 4 .

The direct effect of PCT to LTW was .47. This direct effect can be compared to the total effect of PCT on LTW, which was estimated to be .68, indicating that the relationship between PCT and LTW was partially mediated by PEU and PE. In order to test the significance of indirect effects, unstandardized path coefficients, standard errors for these coefficients, and the standard errors of the indirect effects were used (Sobel, 1982, 1988). Using a z-score to determine significance at $\mathrm{p}<.05$, the indirect effect through PEU was not significant $(\mathrm{z}=$ 1.68 , which is smaller than the absolute value of 1.96). The indirect effect through PE was found to be significant with $\mathrm{z}=2.24$ at $\mathrm{p}<.05$.

\section{Indirect Effects}

\begin{tabular}{|l|c|c|c|}
\cline { 2 - 4 } & $\begin{array}{c}\text { Indirect } \\
\text { Effect }\end{array}$ & $\begin{array}{c}\text { SE for } \\
\text { Indirect } \\
\text { Effects }\end{array}$ & z-score \\
\hline $\mathrm{PCT} \rightarrow \mathrm{PEU} \rightarrow \mathrm{LTW}$ & .09 & .05 & 1.68 \\
\hline $\mathrm{PCT} \rightarrow \mathrm{PE} \rightarrow \mathrm{LTW}$ & .13 & .06 & $2.24^{*}$ \\
\hline
\end{tabular}

Note: * means significant at $p<.05 ;$ PCT (psychological commitment to a team); PEU (perceived ease of use);

$P E$ (perceived enjoyment); and LTW (loyalty to the website)

Therefore, the relationship between PCT and LTW was partially mediated by PE.

\section{Discussion and Conclusion}

The current study empirically tested mediating roles of perceived ease of use and perceived enjoyment on the relationship between a sport fan's psychological commitment to a sport team and loyalty to the team's website. As few studies have investigated how a sport fan develops loyalty to his/her favorite team's website, this study provides fundamental understandings of the use of a sport team's 
website by examining essential psychological constructs in sport fan behaviors.

The results of structural equation modeling analyses revealed that perceived enjoyment is a partial mediating variable when explaining the relationship between psychological commitment to a sport team and loyalty to the team's website. This result supports that perceived enjoyment is one of the key predictors of worldwide-web usage behavior (Atkinson \& Kydd, 1997). Also, this result indicates that individuals who have higher levels of commitment to a team are more likely to enjoy their supporting teams' website, which in turn causes the higher level of loyalty to the team's website. However, unlike the result in Atkinson and Kydd study, perceived ease of use was not a significant mediator in the current study. One explanation not being a mediator could be that psychological commitment to a team has a strong direct effect with a path coefficient of .47 on loyalty to the team's website and thus, attenuates the power of indirect effect through perceived ease of use (Holbert \& Stephenson, 2003). Another possible reason is that sport fans are often extremely loyal and the fans may not care about 'ease of use' of the team's website. Rather, they may seek fun, pleasure, or enjoyable content from the website. Therefore, from the results in the current study, we can deduce that the level of a sport fan's loyalty to the team's website can be accomplished through the degree of his/her commitment to the team and the level of hedonic values (e.g., enjoyment) provided by the website. From the empirical perspective, it is implied that sport marketers should develop and manage hedonic values in a team's website such as live streaming, pictures of players' best performance, fantasy sport, and interviews with favorite players, which may increase sport fans' perception of enjoyment from the website.

The current study is grounded in existing research on media and consumer psychology in terms of its research objectives, model development, and use of sound measures. However, as with most social science research, it has certain limitations, which should be noted and discussed for future recommendations. For example, the current study focused exclusively on the mediating role of two variables (i.e., ease of use and enjoyment) and did not control extraneous variables which may influence the relationship. Other constructs such as utilitarian values or team support should be included to explain how a sport fan develops loyalty to his/her favorite team's website in future studies. In addition, as the current study examined overall usage of a professional team's website, the results may be different if focusing on shopping team-related products (e.g., ticket, jersey) online, joining a fan forum, or bidding an auction. In terms of generalizability, the study was conducted with a sample of college students from one region of the country. Thus, future study needs to employ diverse subjects from different region in order to increase its generalizability.

\section{References}

Atkinson, M., \& Kydd, C. (1997). Individual characteristics associated with world wide web use: An empirical study of playfulness and motivation. The DATA BASE for Advances in Information Systems, 28, 53-62.

Babin, B. J., Darden, W. R., \& Griffin, M. (1994). Work and/or fun: Measuring hedonic and utilitarian shopping value. Journal of Consumer Research, 20, 644-656.

Batra, R., \& Ahtola, O. T. (1990). Measuring the hedonic and utilitarian sources of consumer attitudes. Marketing Letters, 2, 159-170.

Beatty, S. E., \& Kahle, L. R. (1988). Alternative hierarchies of the attitude-behavior relationship: The impact of brand commitment and habit. Journal of the Academy of Marketing Science, 16, 1-10.

Brown, M. T. (2003). An analysis of online marketing in the sport industry: User activity, communication objectives, and perceived benefits. Sport Marketing Quarterly, 12, 48-55. 
Crowley, A. E., Spangenberg, E. R., \& Hughes, K. R. (1992). Measuring the hedonic and utilitarian dimensions of attitudes toward product categories. Marketing Letters, 3, 239249.

Cyr, D., Bonnani, C., \& Ilsever, J. (2004). Beyond trust: Website design preferences across cultures. Journal of Global Information Management, 14, 24-52.

Davis, F. D. (1989). Perceived usefulness, perceived ease of use, and user acceptance of information technology. MIS Quarterly, 13, 319-340.

Davis, F. D., Bagozzi, R. P. \& Warshaw, P. R. (1989). User acceptance of computer technology:

A comparison of two theoretical models. Management Science, 35, 982-1003.

Davis, F. D., Bagozzi, R. P., \& Warshaw, P. R. (1992). Extrinsic and intrinsic motivation to use computers in the workplace. Journal of Applied Social Psychology, 22, 1111-1132.

Dimitriades, Z. S. (2006). Customer satisfaction, loyalty and commitment in service organizations: Some evidence from Greece. Management Research News, 29, 782-800.

Eighmey, J., \& McCord, L. (1998). Adding value in the information age: Uses and gratifications of sites on the World Wide Web: The World Wide Web presents new challenges for advertisers and consumers alike. Journal of Business Research, 41, 187-194.

Eastlick, M. A., Lotz, S. L., \& Warrington, P. (2006). Understanding online B-to-C relationships: An

integrated model of privacy concerns, trust, and commitment. Journal of Business Research, 59, 877-886.

Evanschitzky, H., Iyer, G. R., Plassmann, H., Niessing, J., \& Meffert, H. (2006). The relative strength of affective commitment in securing loyalty in service relationships. Journal of Business Research, 59, 1207-1213.

Filo, K., \& Funk, D. C. (2005). Congruence between attractive product features and virtual content delivery for Internet marketing communication. Sport Marketing Quarterly, 14, 112-122.

Fullerton, G. (2005). The service quality-loyalty relationship in retail services: Does commitment matter? Journal of Retailing and Consumer Services, 12, 99-111.
Hair, J. F., Anderson, R. E., Tatham, R. L., \& Black, W. C. (2005). Multivariate data analysis (6th ed.). Upper Saddle River, NJ: Prentice Hall. Holbert, L., \& Stephenson, M. T. (2003). The importance of indirect effects in media effects research: Testing for mediation in structural equation modeling. Journal of Broadcasting \& Electronic Media, 47, 556-572.

Holmbeck, G. N. (1997). Toward terminological, conceptual, and statistical clarity in the study

of mediators and moderators: Examples from the child-clinical and pediatric psychology literature. Journal of Counseling and Clinical Psychology, 65, 599-610.

Hur, Y., Ko, Y. J., \& Valacich, J. S. (2007). Motivation and concerns of online sport consumption. Journal of Sport Management, 21, 521-539.

Hur, Y., Ko, Y. J., \& Valacich, J. S. (in press). A structural model of the relationships between sport website quality, e-satisfaction, and loyalty. Journal of Sport Management.

Jarvenpaa, S. L., \& Todd, P. A. (1997). Consumer reactions to electronic shopping on the World Wide Web. International Journal of Electronic Commerce, 1, 59-88.

Kaplan, D. (2009). U.S. Open to stream more than 150 matches. Street \& Smith's Sports

Business Journal, 12(17), p. 6.

Kim, D. D., Lindberg, B. M., \& Monaldo, J. M. (2009). Annual industry accounts: Advance

statistics on GDP by industry for 2008. Survey of Current Business, 89, 22-37.

Lin, C. S., Wu, S., \& Tsai, R. J. (2005). Integrating perceived playfulness into expectation-confirmation model for web portal context. Information \& Management, 42, 683693.

Mahony, D. F., Madrigal, R., \& Howard, D. R. (2000). Using the psychological commitment to team (PCT) scale to segment sport consumers based on loyalty. Sport Marketing Quarterly, 9, 15-25.

McMillen, J. D. (2009). The business of sports, volume 1, perspectives on the sports industry. Journal of Sport Management, 23, 392-394.

Moon, J., \& Kim, Y. (2001). Extending the TAM for a World-Wide-Web context. Information \& Management, 38, 217-230.

Moorman, C., Zaltman, G., \& Deshpandé, R. (1992). Relationships between providers and 
users of market research: The dynamics of trust within and between organizations. Journal of Marketing Research, 29, 314-329.

Okada, E. M. (2005). Justification effects on consumer choice of hedonic and utilitarian goods. Journal of Marketing Research, 42, 4353.

Oliver, R. L. (1999). Whence consumer loyalty? Journal of Marketing, 63, 33-44.

Ribbink, D., van Riel, A. C. R., Liljander, V., \& Streukens, S. (2004). Comfort your online customer: Quality, trust, and loyalty on the internet. Managing Service Quality, 14, 446456.

Sobel, M. E. (1982). Aysmptotic confidence intervals for indirect effects in structural equation

models. In S. Leinhardt (Ed.), Sociological Methodology (pp. 290-212). San Francisco, CA: Jossey-Boss.

Sobel, M. E. (1988). Direct and indirect effect in linear structural equation models. In J. S. Long

(Ed.), Common problems/proper solutions: Avoiding error in quantitative research (pp. 4664), Beverly Hills, CA: Sage.
The IAB PWC Advertising Revenue Report. (2010). Internet Ad Revenues Reach Record Quarterly

High of \$6.3 Billion in Q4 '09. Retrieved April 4, 2010 from http://www.iab.net/about the iab/recent_press_releases/press_release_archive /press_release/pr-040710.

Thomson, M., MacInnis, D. J., \& Park, C. W. (2005). The ties that bind: Measuring the strength of consumers' emotional attachments to brands. Journal of Consumer Psychology, 15, 77-91.

Van der Heijden, H., \& Verhagen, T. (2004). Online store image: Conceptual foundations and empirical measurement. Information \& Management, 41, 609-617.

Van Riel, A. C. R., Liljander, V., \& Jurriëns, P. (2001). Exploring consumer evaluations of eservices: A portal site. International Journal of Service Industry Management, 12, 359-377.

Voss, K. E., Spangenberg, E. R., \& Grohmann, B. (2003). Measuring the hedonic and utilitarian dimensions of consumer attitude. Journal of Marketing Research, 40, 310 
